\title{
Peningkatan Kemampuan Gerak Dasar Lokomotor Anak melalui Modifikasi Seni Tradisional Burok
}

\author{
Widiarti $^{1}{ }^{\varpi}$, Elindra Yetti $^{2}$, Nofimarlina Siregar ${ }^{3}$ \\ Pendidikan Anak Usia Dini, Universitas Negeri Jakarta \\ DOI: 10.31004/obsesi.v5i2.1005
}

\begin{abstract}
Abstrak
Seni Burok merupakan jenis permainan tradisional yang sudah dikenal oleh masyarakat daerah Pantura Kabupaten Cirebon. Penelitian ini bertujuan untuk mendeskripsikan proses dan hasil belajar melalui modifikasi seni tradisional burok untuk meningkatkan kemampuan gerak dasar lokomotor anak. Penelitian ini menggunakan metode penelitian campuran. Dilakukan 12 pertemuan dibagi menjadi dua siklus. Teknik analisis data yang digunakan adalah analisis data kualitatif dan kuantitatif. Kemampuan gerak dasar lokomotor meningkat pada siklus pertama dibandingkan pada pra siklus dan meningkat lagi setelah siklus kedua. Peningkatan tersebut membuktikan bahwa permainan seni Burok dapat melatih gerak dasar lokomotor dimensi berjalan, dimensi berlari, dimensi melompat, selain itu dapat melatih kemampuan mendengar, kemampuan berbicara, kemampuan berperan serta kemampuan keterampilan.
\end{abstract}

Kata Kunci: kemampuan gerak dasar lokomotor; seni tradisional burok; anak usia dini

\begin{abstract}
Burok art is a type of traditional game that is well known by the people of the Pantura area of Cirebon Regency. This study aims to describe the process and learning outcomes through modification of the traditional art of burok to improve children's locomotor basic movement skills. This study uses a mixed research method. There were 12 meetings divided into two cycles. The data analysis technique used is qualitative and quantitative data analysis. The basic locomotor motion ability increased in the first cycle compared to the pre cycle and increased again after the second cycle. This increase proves that the art game of blurry can train the basic locomotor motion of the walking dimension, the running dimension, the jumping dimension, besides that it can train listening skills, speaking skills, the ability to participate and the skills skills.
\end{abstract}

Keywords: basic locomotor mobility; traditional art of burok; early childhood

Copyright (c) 2021 Widiarti, Elindra Yetti, Nofimarlina Siregar

$\triangle$ Corresponding author :

Email Address : widiarti1086@gmail.com ( Jakarta, Indonesia )

Received 26 December 2021, Accepted 13 January 2021, Published 15 January 2021 


\section{PENDAHULUAN}

Kemampuan dasar lokomotor yang dimiliki oleh anak pada hakikatnya merupakan hal dasar yang harus dapat dilakukan oleh anak sesuai dengan perkembangan usianya (U. Y. Utari \& Indahwati, 2015). Namun sebagian anak masih merasakan kesulitan dalam melakukan gerakan dasar lokomotor. Kesulitan tersebut yang dapat menyebabkan terhambatnya perkembangan anak sehingga gerakan anak akan sangat minim. Gerakan dasar lokomotor dapat dikatakan berkembang apabila anak terampil dalam menggunakan koordinasi anggota tubuhnya seperti berjalan, berlari, membungkuk, mengayuhkan kaki dan tangan, meloncat, berjalan meliuk ke kanan dan ke kiri. Dalam hal ini anak akan lebih sigap dan luwes dalam pergaulan dengan teman-teman di sekitarnya. Selain itu, anak yang memiliki kemampuan dengan gerakan dasar lokomotor yang baik akan dapat membantu dirinya menampilkan sikap yang baik dan terampil menyelesaikan persoalan yang dialami oleh anak tersebut dalam kehidupan sehari-hari.

Peningkatan kemampuan gerak dasar lokomotor anak tidak selalu berjalan dengan baik, pada kenyataannya di lapangan tidak sejalan dengan teori seperti di atas, masih terdapat guru dan orangtua yang lebih cenderung menekankan agar anaknya lebih pandai dalam membaca, berhitung dan menulis dari pada melakukan keterampilan fisik lainnya, terlebih lagi pada zaman sekarang anak lebih banyak menghabiskan waktu bermain dengan aktivitas non fisik seperti bermain game dan nonton televisi. Hal tersebut dikarenakan masih banyak orangtua yang selalu memberikan gadget kepada anak agar anak lebih tenang dan tidak mengganggu aktivitas yang dilakukan oleh orangtuanya, sehingga orangtua akan merasa lebih nyaman dan tenang melakukan aktivitas tersebut.

Peningkatan kemampuan gerak dasar lokomotor anak usia dini dapat dilakukan melalui permainan tradisional, salah satu bentuk permainan tradisional yang dapat digunakan adalah permainan seni burok yang dimodifikasi dengan gerakan yang diajarkan secara rutin kepada anak. Permainan seni burok ini merupakan permainan yang sering dilakukan dan dilaksanakan oleh masyarakat daerah pantura pada saat acara sunatan atau hajatan, hanya saja jenis permainan ini biasanya dimainkan oleh orang dewasa. Permainan ini adalah permainan yang memiliki asal usul sebagai bentuk replika dari hewan burok yang dijadikan hewan tunggangan Nabi Muhammad S.A.W pada saat menuju langit untuk pembersihan diri. Dimana ajaran tersebut yang membawakannya adalah sunan gunungjati yang memiliki nama asli Raden Fatah.

Berbagai penelitian telah banyak dilakukan tentang bagaimana pentingnya cara menstimulasi gerak dasar lokomotor pada anak saat masih usia dini yang bertujuan agar pada masa selanjutnya seluruh kinerja otot-otot anak tersebut dapat berkembang dengan baik sehingga setiap aktivitas yang dilakukan oleh anak dapat dilakukan dengan baik dan maksimal. Gerakan dasar lokomotor yang dimilik oleh anak yang lebih tua lebih memuaskan bila dibandingkan dengan anak yang lebih muda, perbedaan tersebut dikarenakan adanya pembiasaan atau latihan yang dilakukan setiap harinya (Dourou et al., 2017). Berdasarkan pernyataan Eleni juga bahwa perbedaan anak laki-laki dan anak perempuan memiliki gerakan lokomotor yang berbeda (Dourou et al., 2017). Pernyataan eleni ini menjelaskan bahwa gerakan anak laki-laki dan perempuan memiliki perbedaan dalam hal kontrol dan kelincahannya, karena anak laki-laki akan lebih lincah namun agak kurang dari segi kontrolnya dan sebaliknya anak perempuan memiliki kelincahan yang sedikit lemah namun memiliki kontrol yang baik.

Gerakan dasar lokomotor dapat berfungsi dengan baik bilamana saat usia dini gerakan lokomotornya sudah mengalami pematangan, karena Melalui pematangan gerakan dasar lokomotor saat anak usia dini dapat menjadi bekal yang baik untuk memulai awal perkembangan gerakan lokomotor di saat dewasa nantinya (Melo, 2013). Begitupun pernyataan yang hampir sama dengan melo bahwa Perkembangan dasar lokomotor anak usia dini sangat dipengaruhi oleh pelatihan jasmani yang dilakukan oleh anak setiap harinya, 
dengan pelatihan jasmani yang dilakukan oleh anak maka anak akan mulai terbiasa menggerakkan anggota badan mulai dari gerakan dasar lokomotornya (Lemos et al., 2012).

Gerak dasar lokomotor dapat dikembangkan secara maksimal oleh anak di kala anak memiliki persepsi yang kuat bahwa dia dapat melakukannya dengan baik di saat melakukan latihan (Mukherjee et al., 2011). Pemberian stimulus terhadap kemampuan gerak dasar lokomotor anak menunjukkan bahwa perlu adanya kajian ilmiah yang mengenai tentang faktor apa saja yang mempengaruhi kemampuan gerak dasar lokomotor anak khususnya pada anak usia dini. Adanya anak yang mengikuti program latihan mengalami peningkatan kemampuan gerak dasar lokomotor yang dinilai melalui skor PDMS-2, pada temuan penelitian ini yang menjadi kunci bahwasanya gerakan lokomotor anak akan semakin meningkat bilamana anak tersebut diberikan sebuah latihan yang teratur dan anak mengikuti sesuai instrukturnya (Wang et al., 2010).

Senada dengan apa yang disampaikan oleh wang, di sekolah Dasar juga anak yang memiliki kemampuan gerakan lokomotor yang masih kurang dapat diterapkan latihan tambahan agar anak tersebut dapat maksimal gerakannya, dimana latihan yang diterapkan tersebut dinamakan. Anak yang mengikuti kegiatan latihan yang terstruktur akan mulai terbiasa untuk melakukan sebuah gerakan dimulai yang paling ringan sampai yang terumit, bagi sebagian anak yang merasa sulit untuk melakukan gerakan tersebut memang akan merasakan kesusahan yang dikarenakan anggota tubuh satu dengan yang lain belum terkoordinasi secara bersamaan, namun di saat sudah mulai memasuki yang berikutnya dia akan mulai memahami bahwa gerakan yang seharusnya seperti yang telah diajarkan, dan pada kegiatan yang selanjutnya lagi anak akan mulai terbiasa untuk melakukannya. Namun bagi anak yang tidak mau mengikuti kegiatan latihan maka saat itu anak akan lebih banyak diam melihat teman-temannya, Selain itu anak yang cenderung tidak aktif dapat menyebabkan terhambatnya perkembangan yang berkelanjutan di kemudian hari saat anak tersebut dewasa (Knapik et al., 2013).

Dalam terminologi ilmu perkembangan motorik, gerak dasar disebut dengan istilah Fundamental Movement yang melibatkan unsur-unsur dasar perkembangan tertentu dari gerakan satu macam saja. Gerak dasar merupakan kegiatan yang sangat ideal diberikan pada masa anak-anak dengan memperhatikan beberapa persyaratan seperti yang dikemukakan oleh Rahayu (2019), diantaranya : (a) tubuh anak lebih lentur bila dibandingkan dengan anak remaja ataupun orang dewasa sehingga anak dapat dipastikan akan lebih mudah dalam menerima pelajaran, (b) anak-anak akan lebih mudah dalam mempelajari keterampilan yang baru diberikan, (c) secara keseluruhan anak-anak lebih berani pada waktu kecil jika dibandingkan setelah dia dewasa, karena itu anak akan lebih berani untuk mencoba sesuatu yang dianggap menarik dan baru bagi dirinya sehingga anak tersebut dapat termotivasi untuk belajar.

Gerak dasar lokomotor yang dapat dikembangkan pada masa anak-anak diantaranya berlari, melompat, berjalan, bergeser (Hanief \& Sugito, 2015). Sedangkan gerak dasar manipulatif yang perlu dikembangkan diantaranya mengangkat, melempar, menendang, menekuk. Semua gerakan tersebut merupakan bagian dari gerakan lanjut dai gerakan dasar yang lebih kompleks. Apabila seseorang dapat menguasai keterampilan gerak yang lebih kompleks, maka hal itu sangat dipengaruhi pengalaman gerak dasar yang telah dikuasai oleh dirinya sendiri.

Penelitian yang dilakukan oleh Louise (Hardy et al., 2010) menyatakan anak yang dilakukan program latihan rutin terhadap gerak dasar lokomotor memiliki peningkatan perkembangan gerakannya. Dalam hal ini menunjukkan bahwa anak yang terbiasa melakukan gerakan dasar akan aktif di berbagai kegiatan gerakan. Selanjutnya Gerak merupakan salah satu bagian dari perkembangan fisik-motorik yang bersifat gerakan utuh. Gerak adalah gerak anggota badan secara kasar atau keras, menurut rahayu (Rahayu, 2019) semakin anak bertambah dewasa dan kuat tubuhnya maka gaya geraknya semakin sempurna. Hal ini berakibat tumbuh kembang otot semakin besar dan menguat. Dengan membesar dan 
menguatnya otot tersebut keterampilan baru selalu bermunculan dan semakin bertambah kompleks.

Latihan fisik berupa kemampuan dasar yang dilakukan oleh anak sehari-hari merupakan hal yang primer dalam membentuk sistem kerja tubuh anak (Giriwijoyo \& Sidik, 2010). Dalam hal ini yang berarti bahwa kemampuan dasar yang meliputi gerak lokomotor anak sangat berpengaruh terhadap perkembangan anak dimasa yang akan datang. (Achroni, 2012) menyatakan Gerak dasar lokomotor dalam konteks permainan tradisional adalah gerak fisik yang membutuhkan keseimbangan dan koordinasi antara anggota tubuh dengan mengagunkan otot-otot besar sebagian atau seluruh anggota tubuh. Sedangkan gerak dasar lokomotor sendiri menurut Hanief \& Sugito (2015) adalah gerak memindahkan tubuh dari satu tempat ke tempat yang lain. Gerak dasar lokomotor menurut Richard Decaprio (2013) adalah gerakan tubuh yang menggunakan otot-otot besar atau sebagian besar otot yang ada dalam tubuh maupun seluruh anggota tubuh yang dipengaruhi oleh kematangan diri.

Latihan fisik harus diajarkan kepada anak usia dini agar anak memiliki kemampuan gerak dasar motorik terutama gerak lokomotor yang baik. Hal ini tentunya agar anak tersebut dapat memiliki perkembangan yang bagus bagi anak di masa yang akan datang (Lemos et al., 2012). Begitu pula yang dilakukan oleh dalam penelitiannya yang menyatakan bahwa dari anak yang dijadikan sebagai objek penelitian dan dilakukan latihan gerak dasar lokomotor secara rutin, memiliki gerak dasar loomotor yang meningkat (Tsapakidou et al., 2014). Hal senada juga dinyatakan oleh eleni (Dourou et al., 2017)

Anak yang kurang melakukan aktivitas gerak biasanya memiliki berat badan yang gemuk karena tidak adanya pembakaran lemak tubuh sehingga anak kurang mampu melakukan gerakan lokomotor yang baik. Maka dari anak usia dini inilah anak sangat dianjurkan untuk selalu rutin melakukan latihan gerak dara lokomotor agar anak dapat menyusutkan berat badannya dan memudahkan anak untuk melakukan gerakan lainnya seperti berlari-lari dan melompat-lompat dengan sukaria (Cardon et al., 2019). Gerak dasar lokomotor adalah Kemampuan Anak beraktivitas dengan menggunakan otot-otot kasar. Unsur bekerjanya gerak dasar yaitu berasal dari otak, saraf kemudian otot.

Ketiga unsur diatas melaksanakan masing-masing perannya secara interaksi positif. Artinya, unsur yang satu saling berkaitan, saling menunjang, saling melengkapi dengan unsurnya untuk mencapai kondisi gerak yang lebih sempurna keadaannya. Anak yang otaknya mengalami gangguan tampak kurang terampil menggerak-gerakan tubuhnya. Berdasarkan tiga unsur diatas bentuk perilaku gerak yang dimunculkan terbagi menjadi dua bentuk, yaitu motorik kasar (melibatkan otot-otot besar, saraf dan otak) yang termasuk di dalamnya melibatkan gerakan dasar, dan motorik halus (melibatkan otot-otot kecil, saraf dan otak).

Hasil observasi yang telah dilakukan oleh peneliti melalui instrument dan observasi pada kelompok B di TK Islam Al Kahfi desa Kudukeras kecamatan Babakan kabupaten Cirebon selama satu bulan yaitu pada tanggal 18 November 2019 hingga 14 Desember 2019 menunjukkan bahwa dari 15 anak yang memiliki gerak dasar lokomotor rendah sebanyak 12 anak, yaitu sebesar $80 \%$. kemampuan gerak dasar lokomotor tersebut meliputi adanya anak yang belum dapat melakukan kegiatan seperti melompat satu kaki tanpa terjatuh, melompat satu kaki secara bergantian, berjalan dengan satu kaki secara bergantian atau engklek, melompat satu kaki dengan membawa benda, berjalan berlari dengan membawa benda, melompat kaki kanan ke kiri dan ke belakang tanpa terjatuh, berlari dengan membawa benda, dan meloncat dengan membawa benda. Partisipasi dan keaktifan anak masih dikatakan kurang karena anak lebih banyak duduk di karpet. Pemahaman anak tentang kebudayaan daerah masih dikatakan kurang, salah satunya dalam mengenalkan berbagai permainan seni tradisional yaitu seni burok.

Seni Burok merupakan jenis permainan tradisional yang sudah dikenal oleh masyarakat daerah pantura salah satunya adalah daerah Kabupaten Cirebon. Di Kabupaten Cirebon jenis Permainan tradisional tersebut dimainkan saat hajatan atau sunatan anak. 
Disamping bentuk kesenian Burok juga memiliki beberapa fungsi antara lain fungsi hiburan, yang bagi masyarakat memang menjadi daya tarik ketika kesenian Burok ditampilkan. Selain itu juga fungsi sosial yaitu bila anggota masyarakat menyelenggarakan hajatan dengan menanggap kesenian Burok status sosialnya meningkat.

Dalam permainan Seni Burok agar lebih lengkap biasanya diiringi oleh musik yang dapat memainkan emosional seseorang sehingga dapat memainkan perasaan senang atau gembira, hal ini menandakan bahwa dengan musik seseorang dapat menarik keinginan untuk berekspresi memainkan suatau gerakan yang dimilikinya, memulai dari gerakan dasar yang dimiliki smpai dengan keterampilan gerak yang lebih rumit sekalipun (Giannantonio et al., 2015).

Menurut Hapidin (Hapidin \& Yenina, 2016) jenis permainan tradisional yang dikembangkan oleh guru dapat membangun karakter usia dini. Sedangkan menurut Charles (2017) Permainan tradisional dapat menjadikan salah satu efisiensi dalam meningkatkan keterampilan motorik anak yang meliputi gerak dasar lokomotor anak sekolah, permainan tradisional yang dilakukan dengan skala waktu yang teratur serta durasi waktu yang benar yaitu 3 hari dalam seminggu akan memberikan dampak peningkatan yang signifikan terhadap gerakan anak terlebih lagi bila dilakukan lebih dari tiga hari dalam seminggu maka pastinya akan memberikan dampak yang lebih maksimal lagi. Begitu pula seperti yang dikatakan oleh Chivallero (2017) dalam penelitiannya mengatakan hal yang sama.

Seni Burok adalah seni tradisional khas daerah yang ada di daerah pantura salah satunya Cirebon. Menurut Joko dalam penelitiannya (Pendidikan et al., 2013), yang menyebutkan bahwa Kesenian Burok mulai dikembangkan oleh Sunan Kalijaga untuk mengajak masyarakat berkumpul sekaligus mendengarkan da'wah Agama Islam. seni burok merupakan kesenian rakyat yang berupa boneka kuda terbang namun memiliki wajah yang berparas cantik. Kesenian ini adalah kesenian yang dijadikan simbol sebagai perwujudan kuda terbang yang digunakan oleh Nabi Muhammad SAW pada saat menuju langit yang terjadi pada saat isra dan mi'raj.

\section{METODOLOGI}

Metode penelitian yang digunakan dalam penelitian ini adalah penelitian tindakan (Action Research). Penelitian ini menggunakan model Kemis dan Taggart dimana setiap siklusnya mengikuti langkah-langkah sistematis yang sesuai dengan kaidah penelitian serta kebutuhan penelitian. Desain Penelitian tindakan ini menggunakan Model Kemmis \& Taggart yang terdiri dari empat tahapan yaitu : (1) Perencanaan (Planning), (2) Tindakan (Action), (3) Pengamatan (Obsevation), dan (4) Refleksi (Reflektion). Adapun Desain penelitian Tindakan Kemmis \& Taggart pada gambar 1.

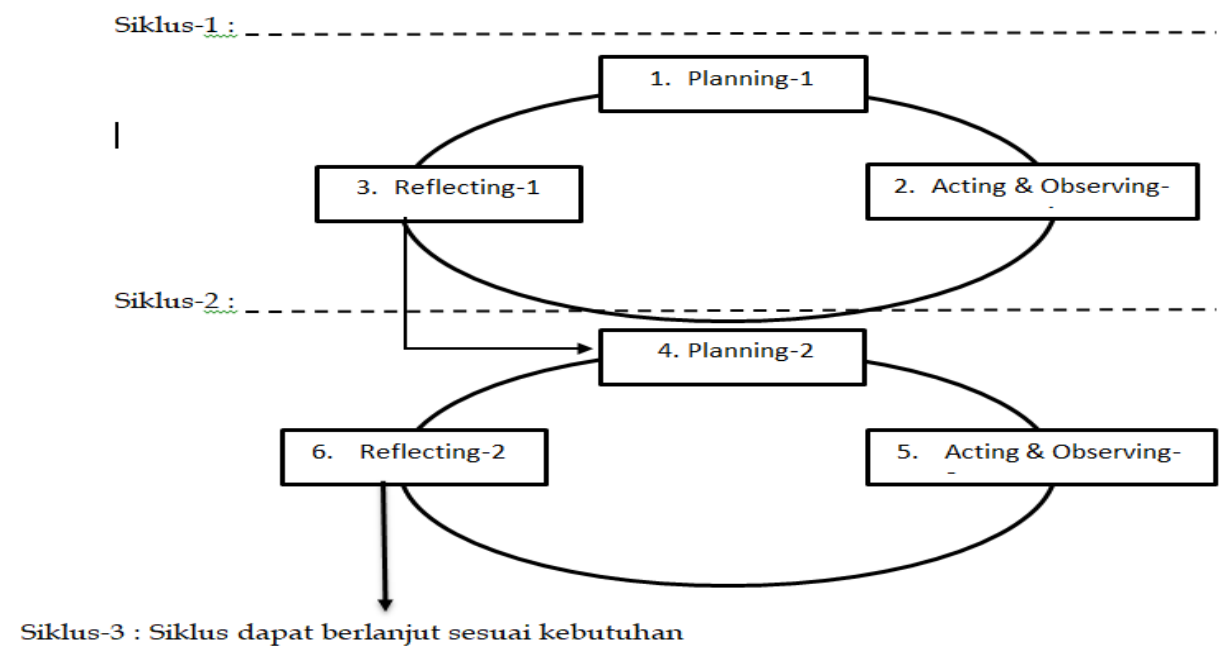

Gambar Desain Penelitian Tindakan 
Adapun skema desain perencanaan kegiatan penelitian ini adalah seperti pada diagram pada gambar 2 .

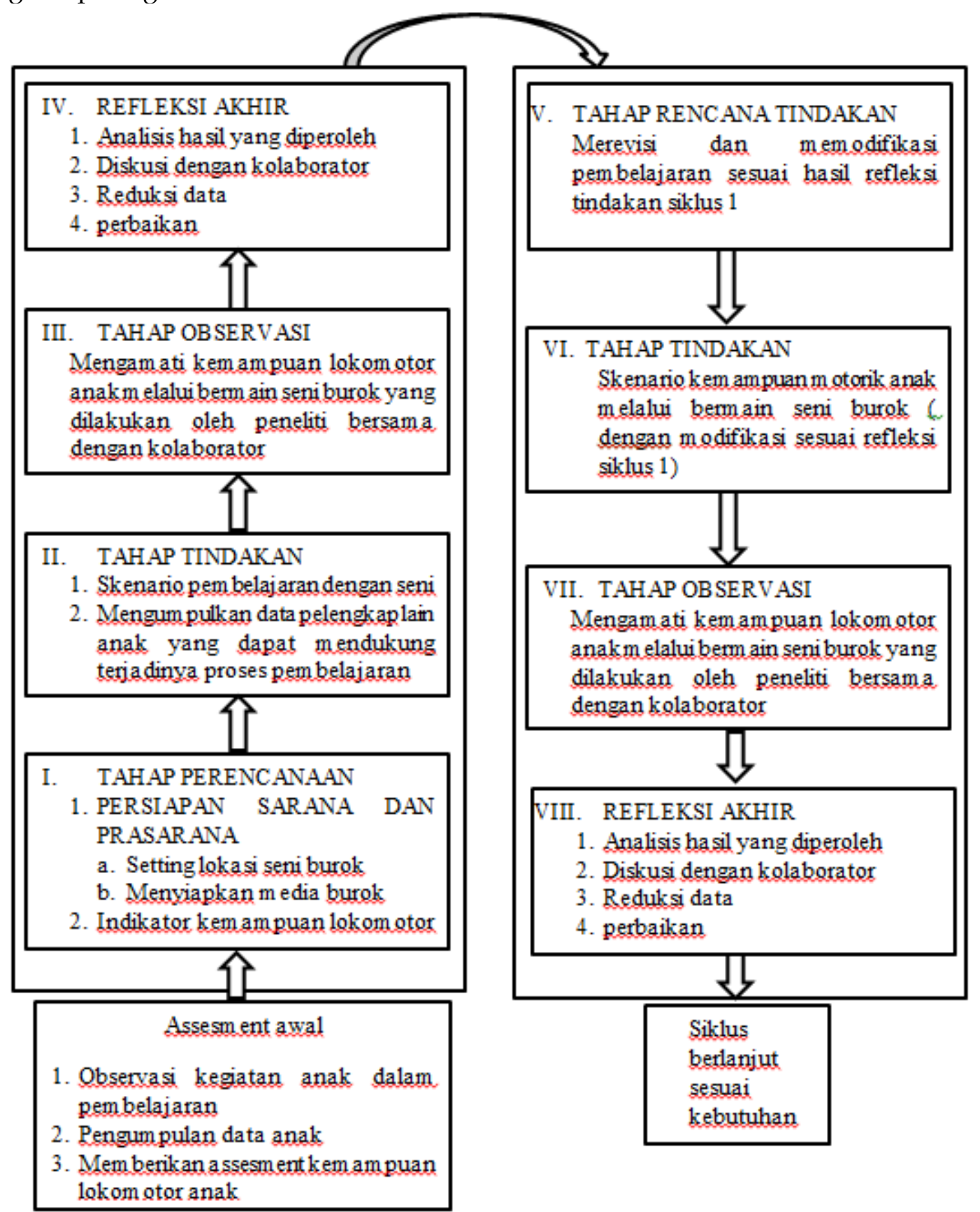

Gambar 2. Skema Desain Perencanaan Penelitian

Penelitian ini menggunakan teknik sampling yaitu purposive sampling, yaitu 15 orang anak kelas B TK Islam Al Kahfi. Dalam penelitian tindakan ini, peneliti tidak melakukan penelitian sendiri namun dibantu oleh kolaborator yang bertindak sebagai perancang/desain sekaligus observer yaitu 2 orang guru kelas B TK Islam Al Kahfi. Jadi peneliti merupakan partisipan aktif yang melakukan observasi / pengamatan serta membantu memberikan tindakan kepada subjek penelitian yaitu gerak dasar lokomotor anak. Pengambilan data dalam penelitian ini yaitu menggunakan instrument penelitian yang sudah dirancang oleh peneliti dan divalidasi oleh beberapa pakar. Selama melakukan penelitian, peneliti bersama kolaborator melakukan pengamatan yang hasilnya akan dievaluasi bersama dan hasil dari tindakan tersebut dapat digunakan sebagai bahan analisis data dan penentuan perencanaan 
untuk melakukan tindakan selanjutnya atau dapat berhenti pada siklus I bila hasilnya telah sesuai dengan yang diharapkan oleh peneliti dan kolaborator.

Data dianalisis menggunakan teknik analisis kualitatif dan kuantitatif. Analisis kualitatif menggunakan metode miles dan Huberman dengan komponen data reduction, data display dan conclusion and verification. Sedangkan analisis data kuantitatif menggunakan studi proporsi.

\section{HASIL DAN PEMBAHASAN}

Berdasarkan hasil observasi awal pra tindakan yang dilakukan pada bulan JuliNovemver 2020, didapat bahwa kemampuan gerak dasar lokomotor yang dimiliki oleh anak kelompok B TK Islam Al Kahfi masih tergolong rendah (12 orang) sehingga peneliti membuat rancangan penelitian tindaakan yang dititik fokuskan pada peningkatan kemampuan gerak dasar lokomotor melalui senib tradisional menggunakan media Burok. Adapun penelitian yang dilakukann menggunakan dua siklus yang terdiri dari 6 pertemuan pada tiap siklusnya, sehingga jumlah yang dilakukan dalam penelitian ini adalah 12 kali dilakukan pada waktu yang diperbolehkan untuk pembelajaran secara tatap muka namun tetap memperhatikan protokol kesehatan.

Pembelajaran yang dilakukan oleh anak usia dini selama masa covid 19 menyebabkan bila hanya berjalan menggunakan media sosial via whatshaps atau melalui zoom meeting anak cepat merasa bosan dan merasa bahwa pembelajaran yang dilakukan tidak terlalu disukai karena tidak dapat dilakukan bersama teman-temannya dalam satu tempat sehingga anak merasa bahwa pembelajarannya dilakukan secara sendiri.

Penelitian pra tindakan yang dilakukan sebelumnya mendapatkan data dengan kategori rendah dikarenakan sebagian besar anak yang mengikuti pembelajaran berkaitan dengan gerakan lokomotor masih banyak yang terjatuh dan kurang keseimbangan seperti "melompat tali" pada kegiatan permainan "jangka" dan terlihat pula hanya sedikit anak yang dapat melakukan gerakan keseimbangan koordinasi badan dengan baik sehingga tidak dapat terjatuh saat melakukan kegiatan tersebut. Kemudian peneliti melakukan wawancara dengan hasil yang diperoleh sebagai berikut: 1). Pembelajaran yang berkaitan dengan gerak lokomotor kepada anak agak kurang diberikan pada saat pembelajaran 2). Pemberian gerak yang berkaitan dengan fisik motorik anak kurang bervariasi 3). Kepala sekolah dan guru sangat setuju dan sangat mendukung dengan akan diadakannya kegiatan seni burak kepada anak terlebih ini juga dapat dijadikan ajang penanaman seni tradisional daerah yang ada di kabupaten Cirebon, harapan yang diutarakan oleh mereka adalah agar anak dapat memiliki gerak dasar lokomotor yang lebih baik lagi dari sebelumnya.

Pada data hasil penelitian kemampuan gerak dasar lokomotor anak saat pra tindakan yang telah dilakukan oleh peneliti dan tim telah didapat bahwa kemampuan gerak dasar lokomotor di TK Islam Al Kahfi khususnya kelompok A masih kurang maksimal yang terbukti dengan anak masih sering terjatuh serta kurang keseimbangan saat melakukan senam lompat. Terlihat dari sejumlah anak tersebut hanya beberapa anak yang memiliki keseimbangan koordinasi tubuh yang baik sehingga anak dapat menjaga keseimbangan dan tidak terjatuh saat melakukan kegiatan senam lompat.

Gambar 3 merupakan grafik hasil dari prosentase data pra tindakan yang diambil sebelum pelaksanaan tindakan berkaitan dengan kemampuan gerak dasar lokomotor anak kelompok B TK Islam Al Kahfi 


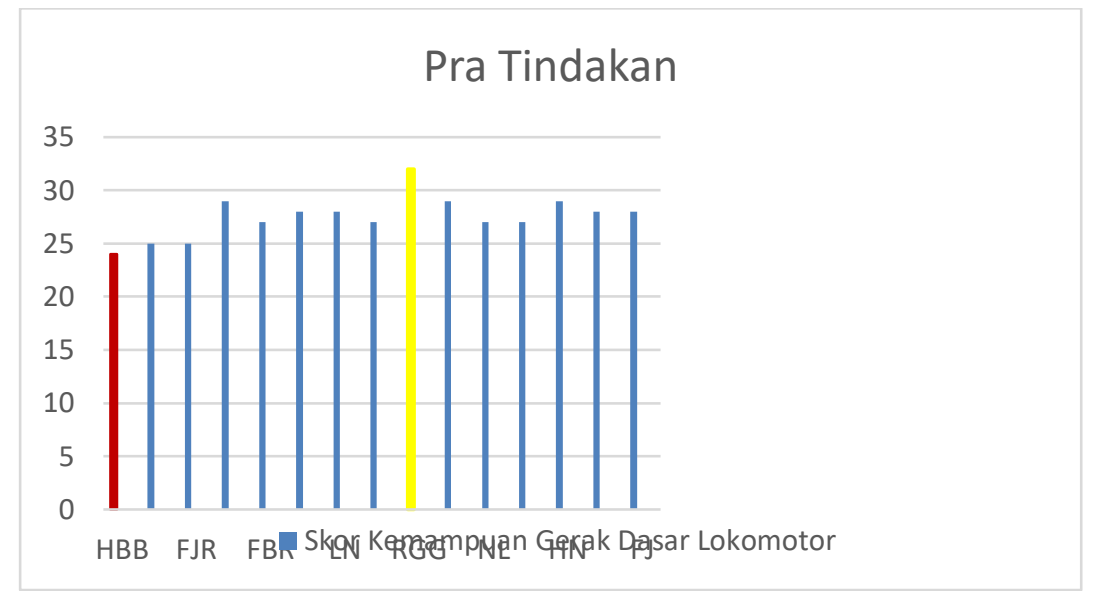

Gambar 3. Grafik skor pra-Tindakan Kemampuan Gerak Dasar lokomotor

Selama beberapa pertemuan yang dilakukan dalam implementasi tindakan yang dilakukan oleh peneliti dan kolaborator secara langsung tentang bagaimana pelaksanaan pembelajaran yang dgunakan untuk meningkatkan kemampuan gerak dasar lokomotor anak pada kelompok B di TK Islam Al Kahfi desa Kudukeras kecamatan babakan kabupaten Cirebon. Observasi yang dilakukan oleh peneliti dan tim kolaborator digunakan untuk mengetahui sejauh mana rencana serta dampak yang dihasilkan dari pelaksanaan tindakan dengan menggunakan seni Burok bagi anak.

Dari hasil observasi serta pemberian tindakan yang dilaksanakan oleh peneliti dan tim kolaborator pada siklus I, peneliti dan kolaborator mengamati jalannya kegiatan untuk melihat apakah kegiatan berjalan sesuai dengan rencana dan hasil yang didapat dalam siklus I dapat berjalan dengan sesuai rencana. Hasil temuan yang didapat dari selama pelaksanaan kegiatan di siklus I adalah anak-anak sangat senang dan menyukai kegiatan yang telah dilakukan yaitu kemampuan gerak dasar lokomotor anak dengan melalui media seni Burok, meskipun kegiatan yang dilakukan tidak dilakukan setiap harinya namun di hari-hari tertentu yang diperbolehkan untuk melakukan tatap muka secara langsung di tengah masa pandemi ini yang tentunya pelaksanaannya disesuaikan dengan protokol kesehatan. Gambaran skor kemampuan gerak dasar lokomotor siklus 1 dapat dilihat pada gambar 4 .

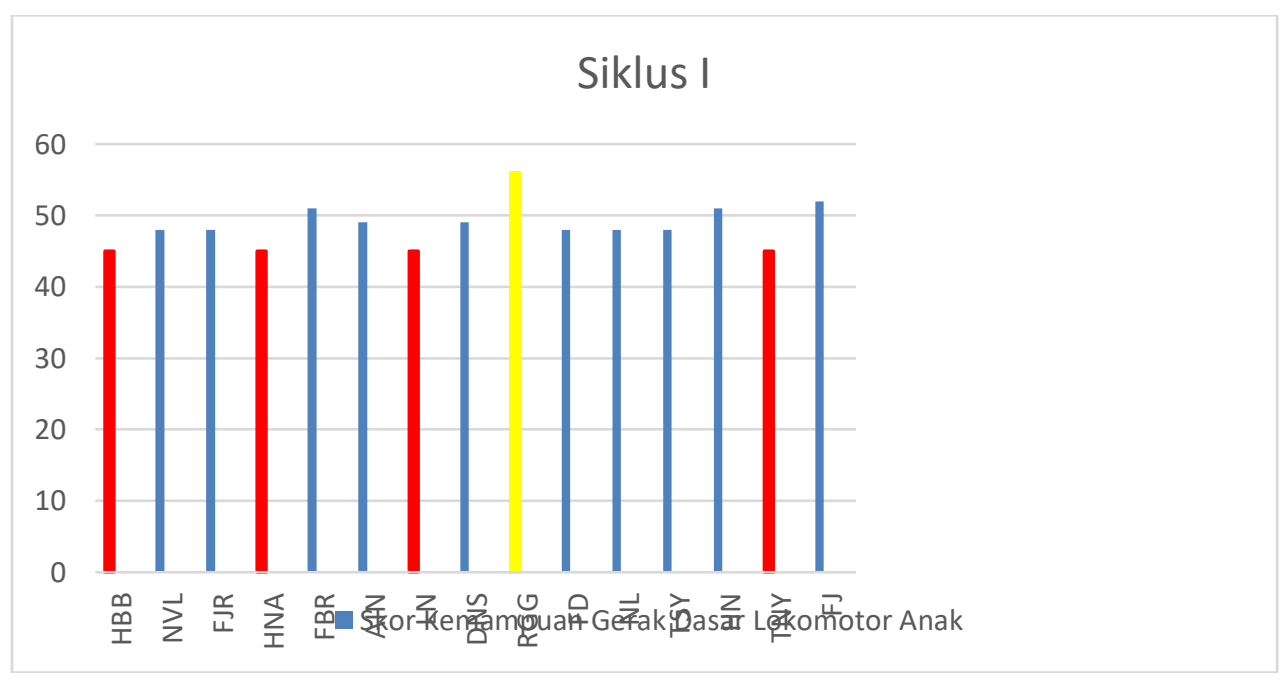

\section{Gambar 4. Grafik Skor Kemampuan Gerak Dasar lokomotor Siklus I}

Berdasarkan hasil observasi dan tindakan yang di dapat dari lapangan, didapat bahwa telah terjadi peningkatan kemampuan gerak dasar lokomotor anak secara keseluruhan mulai 
dari dimensi berjalan, berlari dan melompat. Adanya peningkatan ini disebabkan oleh pembiasaan yang dilakukan oleh anak-anak walaupun tidak dilakukan setiap harinya namun di waktu-waktu tertentu yang diperbolehkan untuk tatap muka sesuai protokol kesehatan di tengah pandemi ini. Gambar 5 merupakan hasil penilaian skor yang diperoleh pada tindakan siklus II.

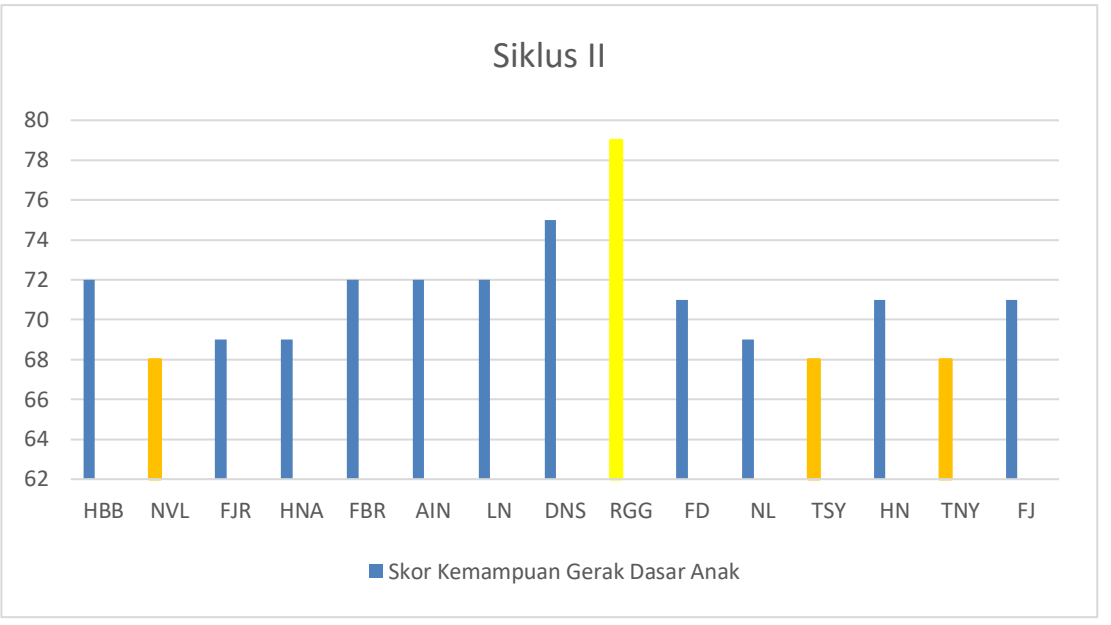

Gambar 5. Grafik Skor Kemampuan Gerak Dasar lokomotor Siklus II

Perkembangan fisik motorik yang dilakukan oleh anak seperti gerak dasar lokomotor akan dapat berkembang meningkat dengan baik apabila anak tersebut diberikan pelatihan dengan berbagai cara melalui aktifitas fisik, aktifitas fisik yang dimaksud di sini salah satunya dengan melalui seni tradisional burok, karena dalam gerakan-gerakan yang terkandung di dalam seni burok merupakan gerakan lokomotor. Seperti yang dikutip dalam jurnal, yoshifumi mengatakan bahwa gerakan dasar lokomotor merupakan dasar dari berbagai keterampilan yang memerlukan adanya latihan serta bimbingan yang akan dapat berkembang pada anak tersebut sehingga anak dapat melakukan dengan baik. Perkembangan gerak dasar lokomotor terjadi melalui tahapan-tahapan yang dilalui oleh anak saat setelah anak memperoleh latihan yang rutin. Hal ini sesuai dengan temuan Hidayah et al. (2017) bahwa pada kelompok anak usia dini, motorik anak dapat diajarkan sesuai dengan perkembangan fisiknya, anak mulai melakukan gerak lokomotor seperti jalan, lari, lompat dan lain-lain. Gerak non lokomotor seperti menggenggam, meremas, mendorong, menarik, mengangkat dan lain-lain. Gerak manipulatif seperti memanjat, menendang, melempar, menangkap, menerima, memantulkan dan lain-lain.

Oleh sebab itu, perkembangan fisik motorik anak akan dapat berkembang secara optimal bilamana diberikan pelatihan yang berisikan dengan aktifitas motorik, slah satu kegiatan fisik motorik yang dapat diberikan adalah dengan menggunakan seni tradisional burok. Seni burok selain dapat melatih perkembangan fisik motorik anak khususnya gerak dasar lokomotor yang berisikan dimensi berjalan, berlari dan melompat juga dapat melatih kognitif anak karena seni burok disajikan dengan adanya alur cerita yang memiliki peranan berbeda-beda sesuai dengan yang telah dibuat oleh peneliti namun memiliki aktifitas yang hampir sama sehingga diperlukan konsentrasi yang baik dari anak tersebut, kemudian selain itu juga anak harus dapat menyeimbangkan gerakan saat membawa media burok agar tidak terjatuh. Dalam kegiatan tersebut terjadi proses anak saat melihat, berpikir dan memahami yang kemudian disalurkan dalam bentuk gerakan yang sesuai dengan peran yang dibawakannya.

Pada saat anak belum diberikan tindakan yang dilakukan oleh peneliti dan kolaborator di lapangan, anak masih memiliki kemampuan gerak dasar lokomotor yang masih minim karena memang di TK Islam Al Kahfi kegiatan pembelajaran lebih banyak kegiatan yang bersifat kognitif dan lebih banyak kegiatan agama. Kemudian pada saat dilakukan observasi 
awal ternyata didapati bahwa anak sering terjatuh pada kegiatan senam fisik serta yang disebabkan anak kurang koordinasi tubuh dengan baik sehingga kemampuan gerak dasar lokomotor anak masih kurang. oleh Karena itu TK Islam Al Kahfi sangat memerlukan kegiatan pembelajaran yang memberikan tindakan agar kemampuan gerak dasar lokomotor anak dapat meningkat.

Pada kegiatan yang dilaksanakan saat siklus I, yang dilakukan sebanyak enam kali pertemuan didampingi oleh guru dimana guru sebelumnya telah mempersiapkan semua perangkat dan kebutuhan yang nantinya digunakan dalam pelaksanaan permainan seni burok saat pertemuan dengan anak-anak. Kegiatan yang dilakukan dalam siklus I selama enam kali pertemuan memberikan dampak yang positif terhadap kemampuan gerak dasar lokomotor anak yaitu dengan kenaikan kemampuan gerak dasar lokomotor walaupun belum memenuhi ketercapaian keberhasilan yang diinginkan oleh peneliti dan kolaborator. Kegiatan tersebut juga dilaksanakan hanya pada hari yang diperbolehkan untuk tatapmuka ditengah pandemi covid 19 yang sedang melanda, namun keterbatasan waktu tersebut ternyata tidak menyurutkan semangat anak-anak dan anak tetap sangat antusias, keinginan untuk ikut berperan memainkan permainan seni burok yang sangat tinggi sebab pada hari yang tidak diperbolehkan untuk tatap muka anak hanya berpaku di depan gadget dalam belajarnya walau melalui zoom meeting. Namun saat diperbolehkan tatap muka inilah rupanya anak sangat senang karena anak dapat bertemu langsung dengan teman-temannya.

Pada kegiatan siklus II merupakan kegiatan lanjutan yang dilakukan yang dikarenakan pada siklus I skor yang dihasilkan belum mencapai keberhasilan yang telah diputuskan yaitu $85 \%$. Saat pelaksanaan siklus II yang juga dilakukan sebanyak enam kali pertemuan juga ternyata memberikan dampak sangat positif dengan semakin bertambahnya kemampuan gerak dasar lokomotor anak. Setiap pertemuan yang dilakukan baik pada siklus I maupun pada siklus II dilakukan dengan cerita yang berbeda setiap pertemuannya, namun kegiatan yang di isi memiliki dimensi yang sama yaitu berjalan, berlari dan melompat. Keunikan cerita permainan membuat anak semangat untuk ikut bermain peran memainkan seni burok. Terkait dengan bermain peran, Damayanti et al. (2018) lebih merekomendasikan bermain peran mikro bebas dibandingkan dengan terpimpin, dengan temuan bahwa bermain peran mikro bebas lebih dapat mengembangkan kecerdasan interpersonal.

Hasil skor kemampuan gerak dasar lokomotor yang baru dimiliki anak pada pra tindakan adalah $34,41 \%$, dan mengalami peningkatan pada siklus I sebesar $60,66 \%$. Adanya peningkatan kemampuan gerak dasar lokomotor yang dimiliki oleh setiap anak tersebut pada siklus I di setiap indikator dalam tiap dimensi kemampuan gerak dasar lokomotor dikarenakan anak mengikuti kegiatan latihan yang diberikan oleh guru berupa aktifitas fisik melalui seni burok, namun peningkatan tersebut belum dapat mencapai target keberhasilan yang diinginkan sehingga perlu diadakan kegiatan lanjutan di siklus II. Selanjutnya pada siklus II, mengalami peningkatan kemampuan gerak dasar lokomotor menjadi $88,66 \%$. Skor yang didapat pada siklus II telah melewati batas minimal keberhasilan yang di inginkan oleh peneliti dan kolaborator dimana batas minimal yang telah disepakati adalah $85 \%$. Dari hasil di atas dapat disimpulkan bahwa seni tradisional burok dapat meningkatkan kemampuan gerak dasar lokomotor anak kelompok B TK Islam Al Kahfi Kecamatan Babakan Kabupaten Cirebon. Senada dengan dengan hasil temuan ini, Y. I. Utari \& Indahwati (2015), mendapati melalui gerakan dasar lokomotor, non lokomotor, dan manipulatif dapat ditingkatkan dengan latihan. Gerak dasar ini sangat penting dalam menunjang kemampuan aktivitas hidup. Dengan demikian dapat dikatakan bahwa gerakan lokomotor dapat menunjang kehidupan anak dimasa dewasanya.

Peningkatan yang terjadi disebabkan oleh adalah latihan yang dilakukan terusmenerus. Hal ini sejalan dengan hasil penelitian (Wang et al., 2010) dimana yang menjadi kunci gerakan lokomotor anak akan semakin meningkat bilamana anak tersebut diberikan sebuah latihan yang teratur dan anak mengikuti sesuai instrukturnya. Perkembangan gerak dasar lokomotor sangat dipengaruhi oleh jasmani. Seperti yang dengan pelatihan jasmani 
yang dilakukan oleh anak maka anak akan mulai terbiasa menggerakkan anggota badan mulai dari gerakan dasar lokomotornya (Lemos et al., 2012). Selain itu, persepsi juga sangat mempengaruhi perkembangan gerak dasar lokomotor anak. Gerak dasar lokomotor dapat dikembangkan secara maksimal oleh anak di kala anak memiliki persepsi yang kuat bahwa dia dapat melakukannya dengan baik di saat melakukan latihan (Mukherjee et al., 2011). Saat melakukan permainan seni tradisional burok, anak-anak merasa senang sehingga tanpa mereka sadari mereka mengembangkan gerak dasar lokomotor.

\section{SIMPULAN}

Peningkatan kemampuan gerak lokomotor anak tersebut pada siklus I dikarenakan anak mengikuti kegiatan seni Burok, namun peningkatan tersebut belum mencapai target keberhasilan yang diinginkan sehingga dilanjutkan pada siklus II. Pada siklus II, mengalami peningkatan melewati batas minimal keberhasilan yang diinginkan oleh peneliti dan kolaborator yang telah disepakati. Dapat disimpulkan bahwa seni tradisional Burok dapat meningkatkan kemampuan gerak dasar lokomotor anak kelompok B TK Islam Al Kahfi Kecamatan Babakan Kabupaten Cirebon.

\section{UCAPAN TERIMA KASIH}

Terimakasih Kepada kepala sekolah, guru dan siswa Taman Penitipan Anak Tambusai atas partisipasinya terhadap penelitian.

\section{DAFTAR PUSTAKA}

Achroni, K. (2012). Mengoptimalkan tumbuh Kembang Anak Melalui Permainan Tradisional. Javalitera.

Cardon, G., Cauwenberghe, E. Van, \& Bourdeaudhuij, I. De. (2019). Physical Activity in Infants and Toddlers. January 2011, 1-5.

Damayanti, R. R., CH, M., \& Hapidin, H. (2018). Pengaruh Bermain Peran Mikro terhadap Kecerdasan Interpersonal. Jurnal Obsesi : Jurnal Pendidikan Anak Usia Dini, 2(1), 34. https://doi.org/10.31004/obsesi.v2i1.5

Dourou, E., Komessariou, A., Riga, V., \& Lavidas, K. (2017). Assessment of gross and fine motor skills in preschool children using the Peabody Developmental Motor Scales Instrument. European Psychomotricity Journal, 9(1), 89-113.

Giannantonio, S., Polonenko, M. J., Papsin, B. C., Paludetti, G., \& Gordon, K. A. (2015). Experience changes how emotion in music is judged: Evidence from children listening with bilateral cochlear implants, bimodal devices, and normal hearing. PLoS ONE, 10(8), 1-29. https://doi.org/10.1371/journal.pone.0136685

Giriwijoyo, H. Y. S. S., \& Sidik, D. Z. (2010). Konsep Dan Cara Penilaian Kebugaran Jasmani Menurut Sudut Pandang Ilmu Faal Olahraga. Jurnal Kepelatihan Olahraga, 2(1), 9.

Hanief, Y. N., \& Sugito, S. (2015). Membentuk Gerak Dasar Pada Siswa Sekolah Dasar Melalui Permainan Tradisional. Jurnal SPORTIF : Jurnal Penelitian Pembelajaran, 1(1), 60-73. https://doi.org/10.29407/js_unpgri.v1i1.575

Hapidin, H., \& Yenina, Y. (2016). Pengembangan Model Permainan Tradisional dalam Membangun Karakter Anak Usia Dini. JPUD - Jurnal Pendidikan Usia Dini, 10(2), 201212. https:// doi.org/10.21009/JPUD.102.01

Hardy, L. L., King, L., Farrell, L., Macniven, R., \& Howlett, S. (2010). Fundamental movement skills among Australian preschool children. Journal of Science and Medicine in Sport, 13(5), 503-508. https:// doi.org/10.1016/j.jsams.2009.05.010

Hidayah, T., Woro Kasmini Handayani, O., \& Artikel, S. (2017). Pengaruh Metode Permainan dan Intelligence Quotient (IQ) terhadap Kemampuan Gerak Dasar Manipulatif pada Siswa Pendidikan Anak Usia Dini (PAUD) Info Artikel. Journal of Physical Education and Sports, 6(2), 172-178. http://journal.unnes.ac.id/sju/index.php/jpes 
Knapik, D. M., Harris, J. D., Pangrazzi, G., Griesser, M. J., Siston, R. A., Agarwal, S., \& Flanigan, D. C. (2013). The basic science of continuous passive motion in promoting knee health: A systematic review of studies in a rabbit model. In Arthroscopy - Journal of Arthroscopic and Related Surgery (Vol. 29, Nomor 10, hal. 1722-1731). Arthroscopy Association of North America. https:// doi.org/10.1016/j.arthro.2013.05.028

Lemos, A. G., Avigo, E. L., \& Barela, J. A. (2012). Physical Education in Kindergarten Promotes Fundamental Motor Skill Development. Advances in Physical Education, 02(01), 17-21. https://doi.org/10.4236/ape.2012.21003

Melo, A. C. M. (2013). Summary for Policymakers. In Intergovernmental Panel on Climate Change (Ed.), Climate Change 2013 - The Physical Science Basis (Vol. 53, Nomor 9, hal. 130). Cambridge University Press. https://doi.org/10.1017/CBO9781107415324.004

Mukherjee, M., Siu, K. C., Katsavelis, D., Fayad, P., \& Stergiou, N. (2011). The influence of visual perception of self-motion on locomotor adaptation to unilateral limb loading. Journal of Motor 101-111. https:/ / doi.org/10.1080/00222895.2010.548420

Pendidikan, J., Drama, S., Musik, D. A. N., Bahasa, F., Seni, D. A. N., \& Semarang, U. N. (2013). Apresiasi masyarakat terhadap kesenian burok grup pandawa nada di desa kemurang wetan kabupaten brebes.

Rahayu, R. J. (2019). Upaya Meningkatkan Hasil Belajar Keterampilan Manipulatif Lengan pada Pembelajaran Model Pendidikan Gerak Berformat Permainan. TEGAR: Journal of Teaching Physical Education in Elementary School, 2(2), 7-28. https://doi.org/10.17509/tegar.v2i2.17638

Richard Decaprio. (2013). Aplikasi Teori Pembelajaran Motorik di Sekolah. Divapress.

Tsapakidou, A., Stefanidou, S., \& Tsompanaki, E. (2014). Locomotor development of children aged 3.5 to 5 years in nursery schools in Greece. Review of European Studies, 6(2), 1-6. https://doi.org/10.5539/res.v6n2p1

Utari, U. Y., \& Indahwati, N. (2015). Upaya meningkatkan gerak dasar lokomotor anak tunagrahita ringan melalui permainan tradisional. Jurnal Pendidikan Olahraga dan Kesehatan, 3(2), 279-282.

Utari, Y. I., \& Indahwati, N. (2015). Upaya Meningkatkan Gerak Dasar Lokomotor Anak Tunagrahita Ringan Melalui Permainan Tradisional (Pada Siswa-Siswi Sekolah Dasar Luar Biasa Tunas Mulya Surabaya). Jurnal Pendidikan Olahraga dan Kesehatan, 3, 279282.

Wang, T. M., Chen, H. L., Hsu, W. C., Liu, M. W., \& Lu, T. W. (2010). Biomechanical role of the locomotor system in controlling body center of mass motion in older adults during obstructed Gait. Journal of Mechanics, 26(2), 195-203. https://doi.org/10.1017/S1727719100003051 